2. Скрипичников, Д.В. Некоторые вопросы законодательства о несостоятельности (банкротстве) Великобритании / Д.В. Скрипичников // Проблемы современной экономики, 2010. - № 2. - С. 276

3. Витрянский, В. В. Пути совершенствования законодательства о банкротстве / В.В. Витряцкий // Вестник Высшего Арбитражного Суда РФ, 2001. - № 3. - С. 91

4. Koral R. L. and Sord M.-Ch. The New Bankruptcy Reorganization Law in France Ten Years Later. 70 American Bankruptcy Law Journal 437, 1996

5. Законодательство США о банкротстве [Электронный ресурс] / Официальный сайт Комитета по вопросам собственности Государственная Дума Федерального Собрания Российской Федерации Режим доступа: http://komitet3-1.test.km.duma.gov.ru/

\title{
Крахмалев Н.С. \\ Понятие, признаки субсидиарной ответственности в рамках дела о несостоятельности (банкротстве)
}

Волгоградский государственный университет

(Россия, Волгоград)

doi: $10.18411 /$ trnio-12-2021-181

\section{Аннотация}

Рассматривая правовое регулирование субсидиарной ответственности на современном этапе, в законодательстве встречаются противоречия и пути их преодоления. Субсидиарная ответственность при банкротстве - это вид гражданско-правовой ответственности при которой субсидиарный ответчик несет дополнительную ответственность по обязательствам основного должника, которая применяется в случаях, установленных законодательством или договором.

Ключевые слова: субсидиарный должник, экономическая деятельность, договор, субсидиарная ответственность, банкротство, несостоятельность, долг, законодательство.

\section{Abstract}

Considering the legal regulation of subsidiary liability at the present stage, there are contradictions in the legislation and ways to overcome them. Subsidiary liability in bankruptcy is a type of civil liability in which the subsidiary defendant bears additional responsibility for the obligations of the principal debtor, which is applied in cases established by law or contract.

Keywords: subsidiary debtor, economic activity, contract, subsidiary liability, bankruptcy, insolvency, debt, legislation.

Внесенные изменения несомненно решили ряд проблем, возникавших при привлечении лиц, контролирующих должника к субсидиарной ответственности. В том виде, в котором субсидиарная ответственность стала выступать в качестве способа обеспечения надлежащей защиты гражданских прав, она, безусловно, решила многие проблемы, связанные с обеспечением пропорционального и справедливого распределения риска между участниками товарно-денежных отношений. Однако некоторые принципиальные вопросы остались без ответа, а также возникло не меньше новых проблем, чем было решено, причем как практического, так и теоретического толка.

Например, статья 399 ГК РФ, которая называется «Субсидиарная ответственность», несмотря на свой значительный объем, не содержит ясного легального определения субсидиарной ответственности, а, скорее, описывает механизм ее применения. Легального определения субсидиарной ответственности нет и в других нормативных актах, принятых на основе Гражданского кодекса РФ. Различные варианты определения субсидиарной ответственности дает наука гражданского права, выделяя в качестве существенных те или иные признаки субсидиарной ответственности. Здесь следует отметить, что среди ученых нет единого мнения в том, является ли субсидиарная ответственность одним из видов гражданско-правовой ответственности, либо же называть это явление ответственностью можно лишь с определенной долей условности. В обоснование второго подхода указывается 
на сущность некоторых субсидиарных правоотношений, которая кроется не в том, чтобы претерпевать определенные имущественные лишения вследствие неправомерного поведения, а в исполнении обязанности за основного должника.

Исходя из вышеизложенного подхода, она предлагает понимать субсидиарное обязательство как возникающее в соответствии с законом либо учредительными документами акцессорное гражданское правоотношение, содержанием которого является право кредитора требовать от учредителя или участника юридического лица (субсидиарного должника) уплаты денежных сумм в размере, определяемом основным обязательством, законом, учредительными документами в случаях, когда юридическое лицо (основной дебитор) не удовлетворил требование кредитора, в том числе при недостаточности имущества либо денежных средств юридического лица.

Однако из приведенного определения не ясно, по каким критериям следует отграничивать субсидиарное обязательство от субсидиарной ответственности и, в итоге, как определить последнюю. Предложенный критерий их разграничения (правонарушение), отсутствует в определении, поэтому данное определение можно применять и к субсидиарному обязательству, и к субсидиарной ответственности, что с учетом предложенной классификации субсидиарных правоотношений является недопустимым. Здесь следует отметить, что такая классификация субсидиарных отношений имеет большую перспективу и должна учитываться законодателем при конструировании новых норм о субсидиарной ответственности и внесении изменений в действующие нормы.

Согласно мнению другого автора Богдановой Е.Е. субсидиарная (дополнительная) ответственность является одним из видов гражданско-правовой ответственности и представляет ответственность одного лица (субсидиарного должника) дополнительно к ответственности другого лица (основного должника). Последнее определение представляется наиболее упрощенным, в нем не указываются дополнительные признаки и основания возникновения субсидиарной ответственности, однако содержится сущность этого вида ответственности, которая совпадает с приведенными ранее определениями других авторов.

Субсидиарная ответственность носит дополнительный, а не самостоятельный характер и вытекает из существа субсидиарного обязательства.

Следует отметить определенную перспективность данной классификации, которая подразумевает различные виды субсидиарной ответственности. Однако с таким делением нельзя согласиться по следующим причинам. Конструкция статутной (объективной, статусной) ответственности, т.е. закрепленной в праве обязанности каждого субъекта вести себя правомерно и потенциальной возможности претерпевать наказание за совершение противоправных поступков вытекает из социально-правового статуса субъекта и является всеобщим масштабом ограничения поступков, противоречащих достигнутому уровню социальной свободы. Эта ответственность возлагается государством на всех лиц в зависимости от объема предоставленных им прав и обязанностей, который закреплен в конституции и других важнейших законах государства. В случае субсидиарной ответственности при банкротстве лиц, контролирующих должника, налицо субъективная ответственность, представляющая собой, в отличие от статутной, меру ограничения свободы конкретного лица, которая начинает действовать при определенных условиях.

Субсидиарная ответственность не может существовать без ответственности основного должника, это противоречит ее сущности. По общему правилу гражданско-правовая ответственность наступает за правонарушение, a, следовательно, субсидиарная ответственность наступает вследствие правонарушения основного должника.

Само по себе банкротство не является гражданским правонарушением, однако оно вызвано невозможностью исполнения обязательств и невозможностью удовлетворения требований кредиторов, вытекающих из этих обязательств вследствие неплатежеспособности или недостаточности имущества юридического лица. Сами требования возникают до признания должника банкротом и основываются на неисполнении 
денежных обязательств (вытекающих из договорных, деликтных и иных отношений) и (или) обязанности по уплате обязательных платежей (которые, по сути, и являются статутной обязанностью). Таким образом, ответственность основного должника вытекает не из самой процедуры банкротства, а из не исполненных ранее обязанностей по гражданско-правовому или трудовому договору, вследствие причинения вреда, неуплате обязательных платежей и др.

Соответственно, в процедуре банкротства должника договорные, деликтные и иные обязательства (имеющие денежный характер), а также обязанность по уплате обязательных платежей объединяются в реестре требований кредиторов и представляют собой размер вреда, причиненного кредиторам, за который основной должник и несет ответственность. Субсидиарный должник несет ответственность не выходящей за пределы ответственности основного должника, а значит, в случае привлечения субсидиарного должника к ответственности, он обязан возместить вред кредиторам равный или меньший того, который закреплен в реестре требований кредиторов. С переложением ответственности с основного должника на субсидиарного, характер обязательств и ответственности не меняется, не меняются также основания возникновения обязанности возместить вред, они по-прежнему остаются договорными, деликтными, налоговыми и др.

Субсидиарная ответственность обладает рядом специфических признаков: а) ее несет лицо, не являющееся нарушителем; б) является дополнительной к ответственности непосредственного нарушителя; в) влечет право регресса к непосредственному нарушителю.

Первый признак субсидиарной ответственности, о котором говорят авторы комментария к Гражданскому кодексу РФ, в данных случаях несостоятелен, а значит и не состоятелен вовсе.

Таким образом, ответственность при банкротстве имеет свои, особые признаки, которые отличают этот вид субсидиарной ответственности от других видов. К числу таких признаков можно отнести следующие: смешанный (договорный, деликтный, налоговый и др.) характер субсидиарной ответственности при банкротстве; ее возникновение вследствие особого юридического факта - юридического состава; наличие в этом составе противоправности, как обязательного условия для привлечения к субсидиарной ответственности; невозможность основного должника удовлетворить требования кредиторов только вследствие отсутствия (недостаточности) имущества, невозможность предъявить регрессное требование к основному должнику, акцессорный характер по отношению к ответственности основного должника, охранительная функция и специальный субъект ответственности, действия которого противоречат требованиям разумности и добросовестности.

Следует отметить, что указанные признаки в совокупности характерны именно для субсидиарной ответственности при банкротстве, в то время, как для субсидиарной ответственности в иных случаях некоторые признаки могут отсутствовать. Кроме того, к перечисленным выше признакам следует отнести еще один, факультативный признак - это наличие причинной связи между противоправным действием (бездействием) и наступившими последствиями (вредом, причиненным имущественным правам кредиторов). Этот признак имеет место в случае привлечения к субсидиарной ответственности контролирующих должника лиц, если банкротство наступило в результате их указаний.

Подводя итог вышесказанному, считаем что под субсидиарной ответственностью, как в общем, так и в случае банкротства, в частности, следует иметь ввиду вид и меру неблагоприятных имущественных последствий, установленные законом или договором и обусловленные сущностью дополняемого ими основного обязательства, налагаемые на лицо, которое в силу закона (при неправомерном поведении) или договора (без вины), обязано произвести исполнение кредитору основного должника в случае отказа последнего от 
исполнения, отсутствия ответа от него в разумный срок или его несостоятельности (банкротства).

1. Прус, Е.П. Проблемы правового регулирования субсидиарных обязательств учредителей (участников) юридического лица : автореф. дис. ... канд.юрид.наук. - М., 2006 г. // Веда. Электронная библиотека. URL:http://www.lib.ua-ru.net/diss/cont/211343.html

2. Богданова, Е.Е. Правовое регулирование субсидиарной ответственности : автореф. дис. ... канд.юрид.наук. Белгород, 2001. Доступ из справ.-правовой системы Консультант Плюс.

3. Кучинский, В.А. Личность, свобода, право. - М., 1978. Доступ из справ.-правовой системы Консультант Плюс.

4. Комментарий к Гражданскому кодексу Российской Федерации (учебно-практический). Части первая, вторая, третья, четвертая / под ред. С.А. Степанова. - 2-е изд., перераб. и доп. - М. Проспект; Екатеринбург: Институт частного права, - 2013. Доступ из справ.-правовой системы Консультант Плюс.

\section{Кудрявцева Л.В., Курганская А.А. Источники международного права}

ФГБОУ ВО «Кубанский государственный Аграрный университет имени И.Т. Трубилина» (Россия, Краснодар)

doi: 10.18411/trnio-12-2021-182

\section{Аннотация}

Понятие источников права многозначно. Под юридическими источниками международного права понимаются те официальные юридические формы (акты), в которых закрепляются нормы права. Перечень источников международного права можно извлечь из содержания ст.1186 ГК РФ. К ним относятся: международные договоры РФ, российское законодательство, обычаи, признаваемые в РФ. В современной доктрине традиционным считается положение о двойственности источников международного права. В этом состоит их специфическая особенность. Такого же мнения придерживается и большинство российских учёных.

Разработка общетеоретических вопросов современного международного права и, в частности, источниковедческих центральных вопросов и проблем имеет не только большое научное, но и большое практическое значение. Выявление закономерностей происхождения источников, а также их взаимодействия дает нам возможность глубже понять современное международное право и учесть тенденции его развития.

Ключевые слова: источники права, международное право, юридические акты, иерархия правовых норм.

\section{Abstract}

The concept of sources of law is ambiguous. The legal sources of international law are understood as those official legal forms (acts) in which the norms of law are enshrined. The list of sources of international law can be extracted from the contents of Article 1186 of the Civil Code of the Russian Federation. These include: international treaties of the Russian Federation, Russian legislation, customs recognized in the Russian Federation. In the modern doctrine, the position on the duality of the sources of the MCHP is considered traditional. This is their specific feature. The majority of Russian scientists hold the same opinion.

The development of general theoretical issues of modern international law and, in particular, the central issues and problems of source studies is not only of great scientific, but also of great practical importance. The identification of the patterns of origin of sources, as well as their interaction, gives us the opportunity to better understand modern international law and take into account the trends of its development.

Keywords: sources of law, international law, legal acts, hierarchy of legal norms. 